\title{
Information Seeking on Covid-19 Pandemic: Care Providers' Experience at the University of Gondar Teaching Hospital, Northwest of Ethiopia
}

This article was published in the following Dove Press journal:

Journal of Multidisciplinary Healthcare

Mulugeta Hayelom Kalayou' Binyam Tilahun'

Berhanu Fikadie Endehabtu' Fedlu Nurhussien ${ }^{2}$

Tesfahun Melese' Habtamu Alganeh Guadie'

'Department of Health Informatics, Institute of Public Health, College of Medicine and Health Sciences, University of Gondar, Gondar, Ethiopia; ${ }^{2}$ Computer Science Department, University of Gondar, Gondar, Ethiopia
Correspondence: Mulugeta Hayelom Kalayou

Department of Health Informatics, Institute of Public Health, College of Medicine and Health Sciences, University of Gondar, Gondar, Ethiopia

Tel +251 919047069

Email Mhayelom5@gmail.com
Background: During the pandemic, information is inevitable and important, and having knowledge on pertinent information is very crucial for health-care professionals in order to deliver sustainable and quality health services to their clients, and to combat the virus. Therefore, the aim of this study was to assess the health-care providers' information seeking behavior on COVID-19 pandemic.

Methods: A descriptive cross-sectional study had conducted among 291 respondents. The participant's characteristics were presented using frequency and percentage. The association between the independent and dependent variables was explained using chi-squared test.

Results: Out of the 291 respondents, 207 (71.1\%) of them had sought information on COVID-19 pandemic. The association between the gender and educational status with the outcome variable was found insignificant. Age $\left(\chi^{2}=10.6, P=0.011\right)$, respondent's working unit $\left(\chi^{2}=33.7, P<0.001\right)$, profession $\left(\chi^{2}=12.7, P=0.013\right)$, taking computer training $\left(\chi^{2}=17.44\right.$, $P=0.000)$, computer access at work place $\left(\chi^{2}=7.28, P=0.007\right)$, internet access at work place $\left(\chi^{2}=22.2, P<0.001\right)$, and frequency of internet use $\left(\chi^{2}=17.63, P<0.001\right)$ were found significant with COVID-19 information seeking.

Conclusion: Information seeking behavior was positively associated with computer access, computer training, internet access and frequency of use. Therefore, comprehensive package is required to build the capacity of care providers on computer-related skills. Besides, institutions need to have internet and computer access.

Keywords: information seeking, COVID-19, pandemic, Ethiopia

\section{Introduction}

The World Health Organization (WHO) declared COVID-19, a new coronavirus disease, a pandemic in January 2020. Since the time of declaration, the virus continues a public health emergency of international concern. ${ }^{1}$ The COVID-19 virus continues to spread around the world. Currently millions of people are affected and hundreds of thousands have died from the coronavirus all over the world. The spread of the disease in Africa is also increasing. ${ }^{2}$ With limited number of tests in Ethiopia the Ministry of Health report showed that the COVID-19 pandemic is becoming a big threat and the virus is at the community level. ${ }^{3}$ Currently in Ethiopia, tens of thousands of people and hundreds of individuals are affected and have died from COVID-19, respectively. ${ }^{4}$ The impact of the virus has been imposed on different sectors like education, economy. and tourism, which leads to a societal, political and economic crisis. ${ }^{5}$ 
COVID-19 poses unprecedented intimidations to global human well-being, and high uncertainty associated with the novelty of COVID-19, many health-care providers rely on different health information sources. ${ }^{6-8}$ During this time, information is inevitable and important, and having knowledge on pertinent information is crucial for health-care providers in order to deliver sustainable and quality health services to their clients. ${ }^{9-12}$ This can be achieved only if the health-care providers have a sustainable access to latest and outdated health related information. ${ }^{13,14}$ Especially in the time of coronavirus, where the nature of the disease and its transmission is not well investigated, and the cure for the disease is not still discovered, seeking information and knowledge sharing are very important to combat the coronavirus disease. ${ }^{8,15}$

Since the introduction of digital solutions, the landscape of information has changed drastically in health systems. $^{6,7,16-20}$ This approach helps care providers in seeking information, which is a purposive searching of information, in order to satisfy their information need. ${ }^{9,10,21,22}$ People in the health systems are using different kinds of electronic information sources besides to the traditional approaches like printed brochures, magazines, and newspapers, colleagues, and family members. The need for information by health-care providers is escalating with the emergence of COVID-19 pandemic around the globe. ${ }^{23}$ Care providers are in need of different kinds of information on the diagnosis, treatment, and medical procedures that are perceived helpful for COVID-19 pandemic control. ${ }^{23-25}$

Social media channels were distinguished as the most important information sources on coronavirus disease, and the other most significant sources of information were digital libraries and publishers' repositories. ${ }^{8,15,16,26,27}$ Besides the abovementioned information sources, television was reported as one of the main sources of information about coronavirus. ${ }^{28}$ Prevention and control methods, mode of transmission and strategies for early recognition of COVID-19 were the most searched information by health professionals. ${ }^{20,28-30}$

Studies showed that people's information seeking and knowledge sharing practice reaches increased heights during emergencies. Since different infectious diseases like HIV/AIDS, tuberculosis, malaria, acute respiratory syndrome (SARS) and Asian bird flu have emerged, and the rate of bioterrorism has increased the need for health information and knowledge sharing practice by the care providers is getting higher and higher. ${ }^{23,31-34}$ The emergence of the COVID-19 pandemic has increased the health-care providers' need of information and information-seeking behavior drastically. ${ }^{15,35-37}$ Even though there are limited studies conducted on the informationseeking behavior in other domains, ${ }^{10,11,38}$ the study conducted on health professionals' information seeking on the COVID-19 pandemic in the case of low-resource setting teaching hospitals is limited. Therefore, the aim of this study was to answer this evidence gap by assessing the information-seeking practice of the care providers.

\section{Method \\ Study Design and Setting}

This study was conducted using an institutional based cross-sectional study design at the University of Gondar teaching and referral hospital from July 10 to July 30, 2020. The University of Gondar Hospital is found in Gondar city, one of the major cities located on the Ethiopia-Sudan border. The area is an investment corridor with hundreds of thousands of laborers, who are engaged in farming. The laborers lives in camps in groups. The hospital has converted many of its facilities into COVID19 health centers. The hospital has been serving as a quarantine and treatment center for the North-West of Ethiopia. The hospital has more than six decades of teaching, research, health service delivery, and community service experience for the North-West of Ethiopia. The average patient visits per day in the hospital outpatient department for the last year was 300. Currently the hospital has around 600 beds in the main wards of the hospital: internal medicine, obstetrics and gynecology, surgical, and pediatric wards.

\section{Sampling and Study Participants}

All health-care providers who were working at the University of Gondar Teaching and Referral Hospital were the source population for this study. A finite population correction formula with a single population proportion ${ }^{39}$ was used to compute the final sample size with the assumptions of $95 \% \mathrm{CI}, 5 \%$ margin of error, $10 \%$ nonresponse rate and a proportion of $50 \%$ for information seeking on COVID-19 pandemic, since there is no a prior research conducted on this. With a nonresponse rate of 27 $(10 \%)$, the final sample size was considered as 300 . To select the participants, we used a systematic random 
sampling technique using a list from the human resource department of the hospital.

\section{Measurement}

The questionnaire was categorized into three parts. The first one was about the sociodemographic characteristics of the respondents, such as age, gender, educational status, working experience, and profession. The second and the third categories were about the technical-related variables and the information-seeking related questions, respectively. COVID-19 information seeking was measured using a question derived from a previous research. ${ }^{15}$ The respondents, were asked

during the past one month, have you ever sought information about COVID-19 PURPOSELY from different sources (Internet, Books, Radio/Television, Newspapers/ magazines, Family and/or Friends)?

The data collection process was conducted using an online survey. Reason for seeking information on COVID-19 were assessed using five options ("first reason", "second reason", "third reason", "fourth reason", "never"). In addition, health professionals' trust in different information sources about COVID-19 were scaled as "a lot", "some", "a little", "not at all".

\section{Data Processing and Analysis}

The data from the respondents were analyzed using SPSS software version 20 . The frequency and percentile were used to describe the sociodemographic characteristics of respondents. The association between the dependent and independent variables or the statistically significant difference between the segments of a dependent variable with the dependent variable was presented in chi-squared test results. A $P$-value of $\leq 0.05$ was considered significant.

\section{Ethical Consideration}

The ethical clearance for this study was obtained from the ethical review board of the University of Gondar. The consent form to the respondents was attached to the front page of the questionnaire with the question to the participants about their willingness to be part of the study. All participants provided informed consent, and the study was conducted in accordance with the Declaration of Helsinki. Due attention was given to not personalize any of the participant's information during data analysis, presentation, and interpretation. Moreover, all the tools used for this research were appropriately acknowledged.

\section{Result}

\section{Social and Demographic Characteristics}

Out of the 300 participants, 291 (97\%) respondent's questionnaires were found valid and ready for analysis. From the total respondents $78(26.8 \%)$ of them were female and $243(83.5 \%)$ of them were degree holders. More than $84 \%$ of the respondents were nurses and medical doctors. The mean age of the respondents was 28.9 years with standard deviation of \pm 4.9 years (Table 1).

\section{Technological-related Variables}

Half of the respondents 147 (50.5\%) and 146 (50.2\%) had computer access at their workplace and took computer training, respectively. Out of the 291 respondents, around $70 \%$ of them were using the internet for COVID-19 information (Table 2).

All respondents were asked for their reason for seeking information on the COVID-19 pandemic. Information

Table I Socio Demographic Characteristics of Health Professionals Working at University of Gondar Teaching and Referral Hospital ( $\mathrm{N}=29 \mathrm{l})$

\begin{tabular}{|l|l|l|}
\hline $\begin{array}{l}\text { Sociodemographic } \\
\text { Characteristics }\end{array}$ & Frequency & $\begin{array}{l}\text { Percentage } \\
\text { (\%) }\end{array}$ \\
\hline $\begin{array}{l}\text { Gender } \\
\text { Female }\end{array}$ & 78 & \\
Male & 213 & 73.8 \\
\hline Age & & \\
20-24 & 45 & 15.5 \\
25-30 & 138 & 47.4 \\
$31-35$ & 78 & 26.8 \\
$35+$ & 30 & 10.3 \\
\hline Educational status & & \\
Diploma & 11 & 3.8 \\
Degree & 243 & 83.5 \\
Masters and above & 37 & 12.7 \\
\hline Work experience & & \\
55 & 101 & 34.7 \\
6-10 & 93 & 31.9 \\
I0-15 & 67 & 23.0 \\
I5+ & 30 & 10.4 \\
\hline Profession & 118 & 40.5 \\
Physicians & 128 & 44.0 \\
Nurses & 9 & 5.8 \\
Midwife & 6.5 \\
Lab technologist & & 3.1 \\
Others & & \\
\hline
\end{tabular}

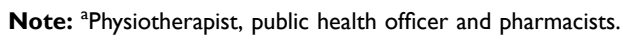


Table 2 Technology-related Variables for Health Professionals Working at the University of Gondar Teaching and Referral Hospital $(\mathrm{N}=291)$

\begin{tabular}{|l|l|l|}
\hline Variables & Frequency & $\begin{array}{l}\text { Percentage } \\
\text { (100\%) }\end{array}$ \\
\hline $\begin{array}{l}\text { Computer access at workplace } \\
\text { Yes }\end{array}$ & 147 & 50.5 \\
No & 144 & 49.5 \\
\hline $\begin{array}{l}\text { Taking computer training } \\
\text { Yes }\end{array}$ & 146 & 50.2 \\
No & 145 & 49.8 \\
\hline $\begin{array}{l}\text { Having an internet access at } \\
\text { workplace }\end{array}$ & & \\
Yes & 185 & 63.6 \\
No & 106 & 36.4 \\
\hline Satisfaction on internet & & \\
Partially satisfied & 168 & 57.7 \\
Not satisfied & 123 & 42.3 \\
\hline Frequency of internet use & & \\
Daily & 160 & 54.9 \\
Weekly & 113 & 38.8 \\
Less than ones in a month & 18 & 6.2 \\
\hline $\begin{array}{l}\text { Using internet for COVID-19 } \\
\text { information }\end{array}$ & & \\
No & & \\
Yes & 205 & 70.4 \\
\hline
\end{tabular}

seeking for diagnosis $113(38.8 \%)$, treatment $100(34.4 \%)$, to find updates on the mode of transmission 137 (47.1\%), to find updates on prevention methods 145 (49.8\%), global and local case reports 144 (49.5\%), and for global and local death reports $116(39.9 \%)$ were their main reasons for seeking information on the COVID-19 pandemic (Table 3). The leading trusted information sources by the respondents, were the CDC 141 (48.5\%), WHO 173 (59.5\%) and the Ethiopian Ministry of Health 137 (47.2\%) websites (Table 4).

\section{Reasons for Seeking COVID-19 Information}

This finding indicated that 113 (33.8\%), $100(34.4 \%)$ and $144(49.5 \%)$ of the respondents first reason for seeking information on COVID-19 were to search for information about the diagnosis, treatment, and for global and local case reports, respectively. Besides, 137 (47.1\%) and 145 (49.8\%) of the respondents first reason for searching for information on COVID-19 was to find updates on the mode of transmission and prevention methods, respectively. Out of the total 291 respondents 17 (5.8\%) of them had never sought information on COVID-19 global and local case reports (Table 3).

\section{Respondents Trust on Information Sources}

This study finding indicated that around $60 \%$ of the respondents had a lot of trust in information disseminated by the WHO website. The Ethiopian Ministry of Health $(\mathrm{EMOH})$ and $\mathrm{CDC}$ websites were also among the highly trusted sources of information by care providers with 137 (47.2\%) and 141 (48.5\%) respondents, respectively. Out of the 291 respondents, 78 (26.9\%) of them had a little trust in information from religious organizations (Table 4).

\section{Health Professionals Information Seeking on COVID-1 9 Pandemic at University of Gondar Teaching and Referral Hospital $(\mathrm{N}=29$ I) 2020}

From the 291 respondents, 207 (71.1\%) of them had an information-seeking behavior on COVID-19 pandemic. Out of them $155(74.9 \%)$ and $176(85.0 \%)$ with information seeking behavior on the pandemic were male participants and degree holders, respectively. Out of the 207 respondents, with positive information-seeking behavior,

Table 3 Reason for Seeking Information on COVID-19 Among Health Professionals Working at the University of Gondar Teaching and Referral Hospital ( $\mathrm{N}=291)$

\begin{tabular}{|l|l|l|l|l|l|}
\hline Reasons & $\begin{array}{l}\text { First } \\
\text { ReasonN (\%) }\end{array}$ & $\begin{array}{l}\text { Second } \\
\text { ReasonN (\%) }\end{array}$ & $\begin{array}{l}\text { Third } \\
\text { ReasonN(\%) }\end{array}$ & $\begin{array}{l}\text { Fourth } \\
\text { ReasonN (\%) }\end{array}$ & \begin{tabular}{l} 
NeverN (\%) \\
\hline For diagnosis
\end{tabular} \\
For treatment & $113(38.8)$ & $79(27.1)$ & $4 I(14.1)$ & $36(12.4)$ & $22(7.6)$ \\
To find updates on the mode of transmission & $100(34.4)$ & $58(19.9)$ & $58(19.9)$ & $43(14.8)$ & $32(11.0)$ \\
To find updates on the prevention methods & $145(49.8)$ & $61(21.0)$ & $39(13.4)$ & $29(10.0)$ & $25(8.6)$ \\
For global and local case reports & $144(49.5)$ & $46(15.8)$ & $38(13.1)$ & $46(15.8)$ & $28(9.6)$ \\
For global and local death reports & $116(39.9)$ & $62(21.3)$ & $33(11.3)$ & $56(19.2)$ & $24(8.2)$ \\
\hline
\end{tabular}


Table 4 Health Professionals Trust on Different Information Sources About COVID-19 Who Were Working at the University of Gondar Teaching and Referral Hospital (N=29I) 2020

\begin{tabular}{|l|l|l|l|l|}
\hline Information Sources & A LotN (\%) & SomeN (\%) & A LittleN (\%) & Not At AIIN (\%) \\
\hline Social media (like Facebook and Twitter) & $73(25.1)$ & $96(33.0)$ & $68(23.4)$ & $54(18.6)$ \\
WHO website & $173(59.5)$ & $49(16.8)$ & $40(13.7)$ & $29(10.0)$ \\
CDC website & $141(48.5)$ & $53(18.2)$ & $57(19.6)$ & $40(13.7)$ \\
Ethiopian Ministry of Health (EMOH) website & $137(47.2)$ & $59(20.3)$ & $56(19.3)$ & $38(13.1)$ \\
Newspaper and magazine & $46(15.8)$ & $87(29.9)$ & $97(33.3)$ & $61(21.0)$ \\
Religious organizations & $54(18.6)$ & $76(26.2)$ & $82(28.3)$ & $7826.9)$ \\
Family members & $41(14.1)$ & $86(29.6)$ & $48(16.5)$ & $116(39.9)$ \\
\hline
\end{tabular}

$170(82.1 \%)$ of them used the internet for COVID-19 information seeking (Table 5).

The chi-squared association result showed that many variables had significant associations with information seeking behavior on COVID-19 pandemic. Age $\left(\chi^{2}=10.6\right.$, $P=0.011)$, profession $\left(\chi^{2}=12.6, P=0.013\right)$, respondents working unit $\left(\chi^{2}=33.6, P<0.001\right)$ and using the internet for COVID-19 information $\left(\chi^{2}=46.9, P<0.001\right)$ were significantly associated with the dependent variable. The chisquared result for sex $\left(\chi^{2}=1.032, P=1.032\right)$ and educational status $\left(\chi^{2}=1.20, \quad P=0.541\right)$ were found insignificant (Table 5).

\section{Discussion}

This study attempts to investigate health professional's information seeking behavior, in the case of COVID-19 pandemic. The finding from this study will serve to identify the health-care providers' possible media sources and their practice in information seeking. The survey result will give a direction for policy makers and ministries to select appropriate information sources to disseminate information related to pandemics like COVID-19. This finding will influence the care providers' engagement in disease control behavior. Besides, the associations of different independent variables with the outcome variable, information seeking practice are discussed hereunder.

Information acquisition practice on COVID-19 pandemic by the participants was found moderate, 207 (71.1\%) of 291participants. The reason for this high finding could be due to the pandemic's nature and the care providers' high information need. ${ }^{6-8}$ The respondents reported they are using different types of platforms for COVID-19 information seeking. Social media (like Facebook and Twitter), WHO website, CDC website, Ethiopian Ministry of Health website, newspaper and magazine, and family members were among the main sources as elucidated in Table 4.

According to the result, the credibility of the information sources were varied. The participants found the WHO and the Ministry of Health websites were highly trusted sources. The possible reason for having a high trust in information disseminated by the WHO and EMOH could be due to the misinformation about COVID-19 from social media sources. ${ }^{16,20}$ COVID-19 related information from religious organizations and family members were less likely to be trusted by the respondents. Their reason for information acquisition on COVID-19 pandemic was mainly to seek information related to diagnosis methods, transmission ways, global and local case and death reports, and for updates on prevention methods. The main reason for searching information about COVID-19 diagnosis and treatment procedure by the care providers could be due to unclear clinical characteristics of the disease. ${ }^{23,24,40}$

It was found that $151 / 207(72.9 \%)$ of the respondents had internet access at their workplace. One hundred and seventy out of $207(82.1 \%)$ of the respondents used the internet for COVID-19 information acquisition. Relative to the technical infrastructure of the low resource settings the respondents were found with a better access to internet and digital devices. The findings of this study also suggest that health professionals still rely on traditional media (eg newspapers and magazines, religious organizations and family members) for COVID-19 information seeking, despite the fact that trust in traditional sources was low. The reason for doubting information from traditional media by the care providers could be due to high misinformation.

Top major facilitating factors for information acquisition on COVID-19 pandemic by health professionals were age $\left(\chi^{2}=10.6, P=0.011\right)$, profession $\left(\chi^{2}=12.7, P=0.013\right)$, respondent's working unit $\left(\chi^{2}=33.7, \mathrm{P}<0.01\right)$. Besides, 
Table 5 Health Professionals with Information-seeking Practice on COVID-19 Pandemic at the University of Gondar Teaching and Referral Hospital ( $\mathrm{N}=207)$

\begin{tabular}{|c|c|c|c|}
\hline Variables & $\begin{array}{l}\text { Respondents } \\
\text { with } \\
\text { Information } \\
\text { Seeking } \\
\text { Behavior }\end{array}$ & Percentage & $P$-value \\
\hline \multicolumn{4}{|l|}{ Age } \\
\hline $20-24$ & 38 & 18.4 & \\
\hline $25-29$ & 87 & 42.1 & $P=0.011$ \\
\hline $30-34$ & 57 & 27.5 & $\chi^{2}=10.6$ \\
\hline 35 and above & 25 & 12.0 & \\
\hline \multicolumn{4}{|l|}{ Sex } \\
\hline Female & 52 & 25.1 & $P=1.032(\mathrm{NS})$ \\
\hline Male & 155 & 74.9 & $\chi^{2}=0.311$ \\
\hline \multicolumn{4}{|l|}{ Educational status } \\
\hline Diploma & 7 & 3.4 & $P=0.541$ (NS) \\
\hline Degree & 176 & 85.0 & $\chi^{2}=1.20$ \\
\hline $\begin{array}{l}\text { Masters and } \\
\text { above }\end{array}$ & 24 & 11.6 & \\
\hline \multicolumn{4}{|l|}{ Profession } \\
\hline Nurses & 83 & 40.1 & \\
\hline Medical doctors & 100 & 48.3 & $P=0.013$ \\
\hline Midwifery & 9 & 4.3 & $\chi^{2}=12.67$ \\
\hline Laboratory & 12 & 5.8 & \\
\hline Others & 3 & 1.5 & \\
\hline \multicolumn{4}{|l|}{ Working unit } \\
\hline $\begin{array}{l}\text { Inpatient/ } \\
\text { outpatient }\end{array}$ & 85 & 41.1 & $P<0.00$ I \\
\hline Other & 122 & 58.9 & $\chi^{2}=33.67$ \\
\hline \multicolumn{4}{|l|}{$\begin{array}{l}\text { Taking computer } \\
\text { training }\end{array}$} \\
\hline Yes & 120 & 57.9 & $P<0.00 I$ \\
\hline No & 87 & 42.1 & $\chi^{2}=17.44$ \\
\hline \multicolumn{4}{|l|}{$\begin{array}{l}\text { Having computer } \\
\text { at work place }\end{array}$} \\
\hline Yes & 115 & 55.6 & $P=0.007$ \\
\hline No & 92 & 44.4 & $\chi^{2}=7.28$ \\
\hline \multicolumn{4}{|l|}{$\begin{array}{l}\text { Internet access at } \\
\text { workplace }\end{array}$} \\
\hline Yes & $15 \mid$ & 72.9 & $P<0.00 I$ \\
\hline No & 56 & 27.1 & $\chi^{2}=27.20$ \\
\hline \multicolumn{4}{|l|}{$\begin{array}{l}\text { Frequency of } \\
\text { internet use }\end{array}$} \\
\hline Daily & 101 & 48.8 & $P<0.001$ \\
\hline Weekly & 96 & 46.4 & $\chi^{2}=17.63$ \\
\hline $\begin{array}{l}\text { Less than } \\
\text { once in a month }\end{array}$ & 10 & 4.8 & \\
\hline
\end{tabular}

(Continued)
Table 5 (Continued).

\begin{tabular}{|c|l|l|l|}
\hline Variables & $\begin{array}{l}\text { Respondents } \\
\text { with } \\
\text { Information } \\
\text { Seeking } \\
\text { Behavior }\end{array}$ & Percentage & P-value \\
\hline $\begin{array}{l}\text { Using internet for } \\
\text { COVID-19 } \\
\text { information }\end{array}$ & & & \\
Yes & 170 & 82.1 & $P<0.001$ \\
No & 37 & 17.9 & $\chi^{2}=46.9$ \\
\hline
\end{tabular}

Note: *Significance at $P<0.05$.

Abbreviation: NS, non-significant.

taking computer training $\left(\chi^{2}=17.44, \mathrm{P}<0.01\right)$, computer access at workplace $\left(\chi^{2}=7.28, P=0.007\right)$, internet access at workplace $\left(\chi^{2}=22.2, P=0.000\right)$, and frequency of internet use $\left(\chi^{2}=17.63, \mathrm{P}<0.01\right)$ were found significant with COVID-19 information seeking. This finding is in line with a study conducted in China. ${ }^{15}$ Therefore, an emphasis on technology-based information sources could positively affect the health professionals' commitment and engagement on combating the COVID-19 pandemic.

\section{Conclusion}

In conclusion, $71.1 \%$ of the respondents had an information seeking behavior on the COVID-19 pandemic. ICT infrastructures like computer access, computer training and internet access at their workplace with frequent internet use were significant with information seeking on the COVID-19 pandemic. Besides, the information disseminated from WHO and Ethiopian Ministry of Health (EMOH) were found among the most highly trusted information sources on COVID-19. Therefore, to better disseminate the useful information regarding COVID-19 to health-care providers the trusted WHO and EMOH websites are recommended. This study assesses the care providers' information seeking behavior about COVID-19 information that advocates information dissemination using reliable sources and digital platforms for enabling health professionals to combat COVID-19 pandemic with other supportive stakeholders.

\section{Limitation}

The major limitation of this study was the small sample size, which had conducted in one teaching and referral hospital. However, the organizational nature of the public hospitals in Ethiopia are similar. 


\section{Acknowledgment}

We would like to acknowledge the study participants.

\section{Author Contributions}

All authors contributed to data analysis, drafting or revising the article, have agreed on the journal to which the article will be submitted, gave final approval of the version to be published, and agree to be accountable for all aspects of the work.

\section{Funding}

There is no funding to report.

\section{Disclosure}

The authors report no conflicts of interest in this work.

\section{References}

1. Chakraborty I, Maity P. COVID-19 outbreak: migration, effects on society, global environment and prevention. Sci Total Environ. 2020;728:138882. doi:10.1016/j.scitotenv.2020.138882

2. Kriston L. Projection of cumulative coronavirus disease 2019 (COVID-19) case growth with a hierarchical logistic model. Bull World Health Organ. 2020. doi:10.2471/BLT.20.257386

3. Abate L, Bekele AE. Status of distribution of coronavirus disease (COVID-19) in Ethiopia within first three months. Acad J Res Sci Publ. 2020.

4. Kebede T, Livestock SD, Resource F, Office D, Kumar D. COVID-19 in Ethiopia: recommendations based on lesson learned from China. Adv Biores. 2020;11-14. doi:10.15515/abr.0976-4585.11.3.12

5. Jamal T, Budke C. Tourism in a world with pandemics: local-global responsibility and action. J Tour Futur. 2020;6(2):181-188. doi:10.11 08/JTF-02-2020-0014

6. Gesualdo F, Romano M, Pandolfi E, et al. Surfing the web during pandemic flu: availability of world health organization recommendations on prevention. BMC Public Health. 2010;10. doi:10.1186/14712458-10-561

7. Hernández-García I, Giménez-Júlvez T. Assessment of health information about COVID-19 prevention on the internet: infodemiological study. JMIR Public Heal Surveill. 2020;6(2):e18717. doi:10.2196/ 18717

8. Bento AI, Nguyen T, Wing C, Lozano-Rojas F, Ahn YY, Simon K. Evidence from internet search data shows information-seeking responses to news of local COVID-19 cases. Proc Natl Acad Sci U S A. 2020;117(21):11220-11222. doi:10.1073/pnas.2005335117

9. Asibey BO, Agyemang S, Dankwah AB. The internet use for health information seeking among Ghanaian University students: a cross-sectional study. Int J Telemed Appl. 2017;2017.

10. Andualem M, Kebede G, Kumie A. Information needs and seeking behaviour among health professionals working at public hospital and health centres in Bahir Dar, Ethiopia. BMC Health Serv Res. 2013;13 (1). doi:10.1186/1472-6963-13-534

11. Kebede M, Hi MPH. Evidence-based practice and its associated factors among medical laboratory professionals in West Amhara hospitals, Northwest Ethiopia. Int J Evid Based Healthc. 2017;1-7. doi:10.1097/XEB.0000000000000122

12. Beshir MA, Woreta SA, Kebede M. Evidence-based practice among health professionals in hospitals of Northwest Ethiopia: a cross-sectional study. Int J Evid Based Healthc. 2017;15:161-170. doi:10.1097/XEB.0000000000000111
13. Alghanim SA. Information needs and seeking behavior among primary care physicians in Saudi Arabia: implications for policy and practice. Sci Res Essays. 2011;6(8):1849-1855. doi:10.5897/SRE11.006

14. Adeola O, Evans O. Digital health: ICT and health in Africa. Aktual'ni Problemy Ekonomiky = Actual Problems in Economics. 2018;208:66-83.

15. Liu PL. COVID-19 information seeking on digital media and preventive behaviors: the mediation role of worry. Cyberpsychol Behav Soc Netw. 2020;23(10):677-682. doi:10.1089/cyber.2020.0250

16. Li HOY, Bailey A, Huynh D, Chan J. YouTube as a source of information on COVID-19: a pandemic of misinformation? BMJ Glob Heal. 2020;5(5). doi:10.1136/bmjgh-2020-002604

17. Winner L. Introduction to Biostatistics and Book. 2004:204.

18. Yoon J, Kim S. Internet use by international graduate students in the USA seeking health information. Aslib J Inf Manag. 2013. doi:10.1108/AJIM-01-2013-0005

19. Lim S, Xue L, Chiuan C, et al. A study on Singaporean women's acceptance of using. Int $J$ Med Inform. 2011;80(12):e189-e202. doi:10.1016/j.ijmedinf.2011.08.007

20. Gupta L, Gasparyan AY, Misra DP, Agarwal V, Zimba O, Yessirkepov M. Information and misinformation on COVID-19: a cross-sectional survey study. J Korean Med Sci. 2020;35(27). doi:10.3346/JKMS.2020.35.E256

21. Gonzalez M, Sanders-jackson A, Emory J. Online health information-seeking behavior and confidence in filling out online forms among Latinos: a cross-sectional analysis of the california health interview survey, 2011-2012. J Med Internet Res. 2016;18:e184. doi:10.2196/jmir.5065

22. Dasgupta N, Yadav AKS, Dasgupta S. Information-seeking behavior of medical professionals in the digital age in Kolkata, India. $J$ Electron Resour Med Libr. 2017;14(1):1-16. doi:10.1080/ 15424065.2016.1261383

23. Spalluto LB, Planz VB, Stokes LS, et al. Transparency and trust during the coronavirus disease 2019 (COVID-19) pandemic. $J$ Am Coll Radiol. 2020;17(7):909-912. doi:10.1016/j.jacr.2020.04.026

24. Lenert L, Mcswain BY. Balancing health privacy, health information exchange, and research in the context of the COVID-19 pandemic. $J$ Am Med Informatics Assoc. 2020;27:963-966. doi:10.1093/jamia/ ocaa039

25. Strekalova YA. Health risk information engagement and amplification on social media: news about an emerging pandemic on Facebook. Heal Educ Behav. 2017;44:332-339. doi:10.1177/ 1090198116660310

26. Gupta L, Gasparyan AY, Misra DP, Agarwal V, Zimba O, Yessirkepov M. Information and misinformation on COVID-19: a cross-sectional survey study. $J$ Korean Med Sci. 2020;35. doi:10.3346/JKMS.2020.35.E256

27. Hernández-García I, Giménez-Júlvez T. Characteristics of YouTube videos in Spanish on how to prevent COVID-19. Int J Environ Res Public Health. 2020;17(13):4671. doi:10.3390/ijerph17134671

28. Abebe A, Mekuria A, Balchut A. Awareness of health professionals on covid-19 and factors affecting it before and during index case in North Shoa zone, Ethiopia, 2020. Infect Drug Resist. 2020;13:2979-2988. doi:10.2147/IDR.S268033

29. Xu C, Zhang X, Wang Y. Mapping of health literacy and social panic via web search data during the COVID-19 public health emergency: infodemiological study. J Med Internet Res. 2020;22(7):1-8. doi:10.2196/18831

30. Sepúlveda-Loyola W, Rodríguez-Sánchez I, Pérez-Rodríguez P, et al. Impact of social isolation due to COVID-19 on health in older people: mental and physical effects and recommendations. $J$ Nutr Heal Aging. 2020;27. doi:10.1007/s12603-020-1469-2

31. Menberu MA. Assessment of knowledge, attitude, practice and willingness of people living with HIV/AIDS to share personal health information to their community in North West Ethiopia. J AIDS Clin Res. 2016;7:2. doi:10.4172/2155-6113.1000550 
32. Groseclose SL, Buckeridge DL. Public health surveillance systems: recent advances in their use and evaluation. Annu Rev ofPublic Heal. 2017;38(1):57-79. doi:10.1146/annurev-publhealth-031816-044348

33. Lapelle NR, Luckmann R, Simpson EH, Martin ER. Identifying strategies to improve access to credible and relevant information for public health professionals: a qualitative study. BMC Public Health. 2006;13:1-13. doi:10.1186/1471-2458-6-89

34. Nölke L, Mensing M, Krämer A, Hornberg C. Sociodemographic and health- (care-) related characteristics of online health information seekers: a cross-sectional German study. BMC Public Health. 2015;1-12. doi:10.1186/s12889-015-1423-0

35. Armitage L, Lawson BK, Whelan ME, Newhouse NN. Paying SPECIAL consideration to the digital sharing of information during the COVID-19 pandemic and beyond. BJGP Open. 2020;4(2): bjgpopen20X101072. doi:10.3399/BJGPOPEN20X101072
36. Parikh PA, Shah BV, Phatak AG, et al. COVID-19 pandemic: knowledge and perceptions of the public and healthcare professionals. Cureus. 2020. doi:10.7759/cureus.8144

37. Bastani P, Bahrami MACOVID-19. COVID-19 related misinformation on social media: a qualitative study from Iran (Preprint). J Med Internet Res. 2020. doi:10.2196/18932

38. Arraid ASKM. Information needs and information seeking behaviour of Libyan doctors working in Libyan hospitals [A Doctoral Thesis]. Libya; 2011.

39. Naing L, Winn T, Rusli BN. Practical issues in calculating the sample size for prevalence studies. Arch Orofac Sci. 2006;1:9-14.

40. Tabata S, Imai K, Kawano S, et al. Clinical characteristics of COVID-19 in 104 people with SARS-CoV-2 infection on the Diamond Princess cruise ship: a retrospective analysis. Lancet Infect Dis. 2020;20 (9):1043-1050. doi:10.1016/S1473-3099(20)30482-5

\section{Publish your work in this journal}

The Journal of Multidisciplinary Healthcare is an international, peerreviewed open-access journal that aims to represent and publish research in healthcare areas delivered by practitioners of different disciplines. This includes studies and reviews conducted by multidisciplinary teams as well as research which evaluates the results or conduct of such teams or healthcare processes in general. The journal covers a very wide range of areas and welcomes submissions from practitioners at all levels, from all over the world. The manuscript management system is completely online and includes a very quick and fair peer-review system. Visit http://www.dovepress.com/testimonials. php to read real quotes from published authors. 